\title{
NOSOCOMIAL INFECTIONS IN THE NEONATAL INTENSIVE CARE UNIT
}

\author{
Vanya RANGELOVA ${ }^{1 凶}$, Ani KEVORKYAN ${ }^{1}$, Maya KRASTEVA ${ }^{2,3}$ \\ ${ }^{1}$ Department of Epidemiology and Disaster Medicine, Medical University of Plovdiv, Plovdiv, Bulgaria \\ 2 Obstetrics and Gynecology ward, Neonatology clinic, St. George University Hospital, Plovdiv, Bulgaria \\ ${ }^{3}$ Department of Obstetrics and Gynecology, Medical University of Plovdiv, Plovdiv, Bulgaria
}

Received 03 Dec 2019, Accepted 29 Jan 2020

hitps://doi.org/10.31688/ABMU.2020.55.1.14

\begin{abstract}
Neonates admitted for intensive care are a highly vulnerable population of patients, susceptible to infections. In newborns, the nosocomial infections have characteristics that are not seen in any other group of patients. The incidence rate of nosocomial infections in newborns is one of the highest and there are differences in this rate between developed and developing countries. The etiology of nosocomial infections in intensive care units is diverse and the causative agents might be bacteria, viruses or fungi. There are numerous risk factors associated with the characteristics of the patients, the hospital-stay and the level of care provided, that might increase the risk of nosocomial infections.
\end{abstract}

Keywords: nosocomial infection, neonate, etiology, incidence, risk factors.

\section{List of abbreviations:}

CDC-Center for Diseases Control and Prevention

CoNS- Coagulase-negative Staphylococcus

CRIB-Clinical Risk Index for Babies

ESBL- extended-spectrum beta-lactamase producing

HAI- hospital-acquired infection

\section{Résumé}

Infections nosocomiales dans l'unité de soins intensifs néonataux

Les nouveau-nés admis dans l'unité de soins intensifs constituent une population particulièrement vulnérable de patients sensibles aux infections. Chez les nouveau-nés, les infections nosocomiales (IN) ont des caractéristiques que l'on ne retrouve dans aucun autre groupe de patients. Le taux d'incidence des IN chez les nouveau-nés est l'un des plus élevés et il existe des différences entre ces taux dans les pays développés et ceux en cours de développement. L'étiologie de NI est diverse et les agents responsables peuvent être des bactéries, des virus ou des champignons. Il existe de nombreux facteurs de risque associés aux caractéristiques de la population de patients, au séjour à l'hôpital et au niveau de soins fournis qui pourraient augmenter le risque d'infection nosocomiale.

Mots-clés: infection nosocomiale, nouveau-né, étiologie, l'incidence, facteurs de risque. 
NEC- necrotizing enterocolitis

NI- nosocomial infection

NICU- neonatal intensive care unit

RSV-respiratory syncytial virus

SENIC-Study on the Efficacy of Nosocomial Infection

Control

SNAP-Score for Neonatal Acute Physiology

VAP-ventilator-associated pneumonia

WHO- World Health Organization

\section{INTRODUCTION}

The improvements in antenatal management during recent years have changed the prognosis of preterm neonates. This has led to a shift of the main population of newborns that are hospitalized and taken care of in the neonatal intensive care units (NICUs). Newborn infants, especially those born prematurely and needing intensive care, are at greater risk of nosocomial infection (NI). They are relatively immunocompromised, often require a prolonged stay in the hospital, and are victims of invasive therapeutic and diagnostic procedures ${ }^{1}$. The infections in the neonatal period have characteristics that do not occur in any other group of patients.

Nosocomial infection, also known as hospital-acquired infection (HAI), is defined by the Centers for Disease Control and Prevention (CDC) as a localized or systemic condition resulting from an adverse reaction to an infectious agent or its toxins, without evidence that the infection was present or incubating at the time of admission to the acute care setting ${ }^{2}$.

Nosocomial infections increase the costs of neonatal intensive care, prolong hospitalization and are responsible for almost $50 \%$ of the deaths that occur under 2 weeks of age ${ }^{3}$. According to extensive studies on the consequences of NI on the national healthcare system, based mainly on Study on the Efficacy of Nosocomial Infection Control (SENIC), 6\% of all nosocomial infections could be prevented by minimal infection control efforts, and $32 \%$ of all nosocomial infections could be prevented by well organized and highly effective infection control programmes ${ }^{4}$. In the present article we present some of the aspects of neonatal NI, such as etiology, incidence and risk factors.

\section{ETIOLOGY OF NOSOCOMIAL INFECTIONS IN NEONATAL INTENSIVE CARE UNITS}

The organisms causing NI include bacteria, viruses and fungi. In healthy term babies the predominant bacterial pathogens are Staphylococcus aureus, enteropathogens and respiratory viruses. In high-risk nurseries there is a broad spectrum of infectious agents that includes microorganisms normally nonpathogenic for term-newborns, such as Coagulase negative Staphylococcus (CoNS) and Candida ${ }^{5}$.

\section{Gram-positive bacteria}

In the developed countries, up to $70 \%$ of the nosocomial infections in the NICUs are caused by Gram-positive microorganisms ${ }^{6}$. The Staphylococcus spp. is the main Gram-positive agent of hospital infection in the newborn, the most important being CoNS. It frequently affects low birth weight newborns with prolonged hospital stay, with venous catheters, and administration of parenteral lipids ${ }^{7}$. According to the literature, CoNS causes $50-70 \%$ of the cases of late-onset sepsis ${ }^{5}$.

Staphylococcus aureus is a common pathogen in nurseries around the world. It causes bloodstream infections, cutaneous and wound infections, osteoarthritis, meningitis and ventriculitis ${ }^{3}$. The main reservoir of this bacterium is the hospital staff and contamination usually occurs through the hands ${ }^{8}$.

The most common source of Enterococcus spp. is the gastrointestinal tract of the newborn ${ }^{7}$. There is also the possibility of colonization of the mouth, respiratory tract, cutaneous lesions, and of contamination by objects and surfaces of the environment ${ }^{9}$. Enterococci are an occasional cause of infections in the NICU. Overall, 6\% of late-onset sepsis cases, 5\% of pneumonias, and $9 \%$ of surgical infections are caused by enterococcal species ${ }^{3}$. Preterm newborns who remain hospitalized for over 30 to 60 days, with prolonged use of venous catheters and exposed to multiple antimicrobials, are especially predisposed to infections by Enterococcus?

\section{Gram-negative bacteria}

According to the literature, approximately 19\% of cases of sepsis and $30 \%$ of pneumonias are caused by Gram-negative bacteria ${ }^{5,10}$. These infections are associated with high lethality rates. Commonly isolated bacteria are E. coli, Klebsiella spp., Pseudomonas aeruginosa, Enterobacter spp., Serratia marcescens. 
Non maternal strains of E. coli (from other patients or environment) can cause invasive diseases ${ }^{11}$. Studies document that E. coli causes $9 \%$ of all nosocomial infections ${ }^{12}$ and $5-13 \%$ of the late-onset bloodstream infections and is one of the leading pathogens in ventilator-associated pneumonia (VAP) alongside with Klebsiella pneumonia and Pseudomonas aeruginos $a^{13}$.

Klebsiella spp., particularly K. pneumonia and K. oxytoca are well-established pathogens in NICU patients that cause sepsis, urinary tract infections, and pneumonia ${ }^{3}$. In recent years in the NICUs, extended-spectrum beta-lactamase-producing (ESBL) Klebsiella spp. have been identified that are resistant to third-generation cephalosporins.

Serratia spp. is mostly nosocomial pathogen and it may cause sporadic cases of pneumonia, meningitis or little epidemic outbreaks with high lethality rate, especially in prematurely born infants ${ }^{14}$.

Pseudomonas aeruginosa is a well-known causative agent of sepsis, conjunctivitis and endophthalmitis and is associated with high mortality rates ${ }^{3}$. This pathogen is the leading causative agent of ventilator-associated pneumonia (VAP) in premature neonates ${ }^{15}$. The epidemiologic importance of this microorganism is supported by its biologic features: production and proliferation of new hospital strains, high antibiotic resistance and ability to persist in a humid environment, including medical equipment for prolonged mechanical ventilation ${ }^{16,17}$.

\section{Fungi}

Different Candida strains (albicans, tropicalis, parapsilosis) account for most hospital infections. Candida spp. cause candidemia, particularly catheter-related bloodstream infection, and less commonly urinary tract infections, endocarditis, osteomyelitis and meningitis?

\section{Viruses}

The most frequent viral nosocomial pathogens are respiratory syncytial virus (RSV) and rotavirus. Hospital staff, family members, and other infected patients represent the main conveyors of viral infections in the neonatal units. The nosocomial viral respiratory infections increase the need for mechanical ventilation, prolong the hospital stay and cause higher medical costs.

\section{INCIDENCE OF NOSOCOMIAL INFECTIONS IN NEONA- TAL INTENSIVE CARE UNITS}

The reported incidence of nosocomial infections depends on a number of factors. In some studies, both perinatal and nosocomial infections are included $^{19}$, while others exclude infections occurring in the first days of life. Other factors are the level of intensive care provided - small units providing care mainly to normal term babies report lower rates than level III intensive care units in which care for critically ill infants is provided ${ }^{20}$. The rate of nosocomial infections is the highest in NICUs compared to other hospital wards, including pediatric and adult intensive care units ${ }^{18}$. The rates of incidence differ depending on the type of hospital, the characteristics of the newborn patients (gestational age, birth weight, associated conditions), on the methods used for the diagnosis of infections and for epidemiologic surveillance?

The most frequent infections in NICUs are bloodstream infections, pneumonia, and necrotizing enterocolitis (NEC); less frequent complications are infections of the eyes, mouth or skin ${ }^{21,22}$.

Significant differences exist between the NICUs and the incidence of nosocomial infections in the group of infants with very low birth weight may vary between $6.7 \%$ to $74.5 \%$, whereas in the group of infants with low or normal birth weight the incidence is between $0.1 \%$ to $17 \%{ }^{23}$. Another factor that might influence the incidence rate is the methodology used for the diagnosis of infection. In some studies, the researchers included only microbiologically proven infection while in others are included both clinically and microbiologically diagnosed infections. In addition, different methods might be used for calculating the incidence. Usually, the incidence is calculated dividing the number of infected patients by 100 hospitalized patients. In the last years more frequently used and accurate is the calculation of the incidence rate using the number of infections in the nominator and in the denominator is the hospital stay/1000 patient-days.

There are differences in the incidence of nosocomial infections between the NICUs in developed and developing countries (Table 1). In the developing countries, the nosocomial infections remain the major reason for preventable morbidity and mortality. Countries in sub-Saharan Africa and South Asia have the highest neonatal mortality caused by nosocomial infections ${ }^{24}$. The main reasons for high morbidity and mortality in those countries are overcrowding, lack of preventive measures, lack of control and inadequate use of the scarce financial resources. An observational study of the incidence of nosocomial infections in developing countries determined that bloodstream infections in those countries are 3 to 20 times more common than in industrial countries ${ }^{25}$. 
Table 1. Nosocomial infections incidence published

in different studies from developed and developing countries.

\begin{tabular}{|c|c|c|c|c|}
\hline Authors & Study Design & Number of patients & $\begin{array}{c}\text { Period, } \\
\text { Place of the study }\end{array}$ & Results \\
\hline Klevens et al. ${ }^{26}$ & $\begin{array}{c}\text { National nosocomial infec- } \\
\text { tion surveillance system } \\
\text { (NNIS) }\end{array}$ & $3,789,310$ neonates & $\begin{array}{l}1990-2002 \\
\text { USA }\end{array}$ & $\begin{array}{l}6.88 / 1,000 \\
\text { patient-days }\end{array}$ \\
\hline Gill et al. ${ }^{27}$ & $\begin{array}{l}\text { Prospective } \\
\text { multicenter }\end{array}$ & $\begin{array}{l}3180 \text { neonates with } \\
\text { birth weight }<1000 \mathrm{gr}\end{array}$ & $\begin{array}{c}2002-2004 \\
\text { Australia, } \\
\text { New Zealand } \\
\end{array}$ & $\begin{array}{l}5.02 / 1,000 \\
\text { patient-days }\end{array}$ \\
\hline Aziz et al. ${ }^{23}$ & $\begin{array}{l}\text { Cohort, } \\
\text { Prospective, } \\
\text { Multicenter }\end{array}$ & $\begin{array}{l}3253 \text { neonates with } \\
\text { weight }<1500 \text { gr. } \\
13244 \text { neonates with } \\
\text { weight }>1500 \mathrm{gr} \text {. }\end{array}$ & $\begin{array}{c}\text { January 1996- October } \\
1997 . \\
\text { Canada }\end{array}$ & $\begin{array}{l}23.5 \% \text { in neonates } \\
\text { with weight }<1500 \mathrm{gr} \\
2.5 \% \text { in neonates } \\
\text { with weight }>1500 \mathrm{gr}\end{array}$ \\
\hline Zingg et al..$^{28}$ & Point-prevalence ECDC & 6750 neonates & $\begin{array}{c}2011-2012 \\
29 \text { EU contry members, } \\
\text { Iceland } \\
\text { Norway Croatia } \\
\end{array}$ & $10.7 \%$ \\
\hline Orsi et al. ${ }^{29}$ & $\begin{array}{c}\text { Cohort } \\
\text { prospective }\end{array}$ & 575 neonates & $\begin{array}{c}2003-2006 \\
\text { Italy }\end{array}$ & $\begin{array}{c}13.2 \% \\
7.8 / 1000 \text { patient-days }\end{array}$ \\
\hline $\begin{array}{c}\text { Djordjevic et } \\
\text { al. }^{30}\end{array}$ & $\begin{array}{c}\text { Cohort } \\
\text { prospective }\end{array}$ & 381 neonates & $\begin{array}{c}1 \text { January- } 31 \text { December } \\
2012 \\
\text { Serbia } \\
\end{array}$ & $\begin{array}{c}19.4 \% \\
9.1 / 1000 \text { patient-days }\end{array}$ \\
\hline Basiri et al. ${ }^{31}$ & $\begin{array}{c}\text { Point-prevalence retrospec- } \\
\text { tive }\end{array}$ & 1000 neonates & $\begin{array}{l}\text { October 2012- March } \\
2013 \\
\text { Iran } \\
\end{array}$ & $\begin{array}{c}5.1 \% \\
7.2 / 1000 \text { patient-days }\end{array}$ \\
\hline Urzedo et al. ${ }^{32}$ & $\begin{array}{c}\text { Cohort } \\
\text { prospective }\end{array}$ & 4615 neonates & $\begin{array}{c}1997-2012 \\
\text { Brazil }\end{array}$ & $\begin{array}{c}14.45 / 1000 \text { pa- } \\
\text { tient-days }\end{array}$ \\
\hline $\begin{array}{l}\text { Mohammed et } \\
\text { al. }^{13}\end{array}$ & $\begin{array}{l}\text { Cohort } \\
\text { prospective }\end{array}$ & 418 neonates & $\begin{array}{c}\text { March 2012- February } \\
2013 \\
\text { Egypt } \\
\end{array}$ & $38.5 \%$ \\
\hline Kilic et al..$^{33}$ & $\begin{array}{c}\text { Cohort } \\
\text { prospective }\end{array}$ & 352 neonates & $\begin{array}{l}\text { July } 2011 \text { - } \\
\text { June } 2012 \\
\text { Turkey }\end{array}$ & $\begin{array}{c}10.5 \% \\
11.5 / 1000 \mathrm{pa}- \\
\text { tient-days } \\
\end{array}$ \\
\hline
\end{tabular}

\section{RISK FACTORS FOR NOSOCOMIAL INFECTIONS IN NEONATAL INTENSIVE CARE UNITS}

The risk factors for hospital-acquired infections (HAI) can be divided in two groups: intrinsic and extrinsic. The intrinsic factors include characteristics such as gestational age, birth weight, severity of the disease, immunologic maturity. These risks are usually outside of the control of the hospital and vary from hospital to hospital, but are important factors in determining whether the patients will develop an infection. Extrinsic risk factors may reside in the patient care staff (practices of an individual care-giver) or the institution (practices in an entire hospital). The extrinsic factors include hospital-stay, use of invasive devices, medications, exposure to hospital environment and hospital staff, hygiene and hospital infection control practices.

\section{Intrinsic risk factors}

- Immunologic immaturity

The immunologic deficits in the newborns affect all aspects of the immune system ${ }^{34}$. The levels of neutrophils and immunoglobulins are lower compared to adults. In premature infants, the antibodies have lower opsonic function for potential pathogens and their ability to produce antibodies under the influence of polysaccharide antigens is reduced. The T-cell function is also disturbed in infants born prematurely.

\section{- Birth weight}

The birth weight is used as one of the most important and stable predictive factor for the expected severity of the disease. The risk of infection is inversely proportional to the birth weight. It also serves as a marker for the immunologic immaturity and underdeveloped mechanical barriers ${ }^{34}$. The strong correlation between low birth weight and the risk of nosocomial infection has been proved in numerous studies ${ }^{1,13,22,30}$. The risk of infection increases by $3 \%$ with every reduction of the birth weight with 500 grams $^{35}$. The strongest correlation between birth weight as risk factor and nosocomial infections has been established for the group of infants with weight between 750-999 grams $^{36}$. 


\section{- Gestational age}

The risk of nosocomial infection is inversely proportional with the gestational age. Premature birth and birth weight are considered the two most important risk factors for $\mathrm{HAI}^{29,35}$. The highest incidence is recorded in children born before 32 weeks of gestation $^{35}$. When considering gestational age as a risk factor for NI, some authors recommend the rate of NI to be corrected based on gestational age, to facilitate a better comparison of data ${ }^{37}$.

\section{Severity of illness}

Substantial variations in outcomes among in fants of the same birth weight have been observed in different NICU's. In order to have better predictors for outcome, neonatal severity of illness scores have been developed. These scores assess underlying physiologic factors that can contribute to outcome. These include the Score for Neonatal Acute Physiology $(\mathrm{SNAP})^{38}$ and the Clinical Risk Index for Babies $(\mathrm{CRIB})^{39}$, which assess physiologic derangements in each organ system at specified intervals during hospitalization (e.g. at admission, at day of life 7). The use of those scores is limited now to research studies, but they might be implemented routinely in everyday practice after validation in a non-research setting.

\section{Extrinsic risk factors}

- Intravenous catheters

The use of umbilical venous catheters for more than 5 days could increase the risk of sepsis by 21 times, whereas considering arterial catheters the risk is 16 times higher ${ }^{40}$. The prolonged use of central or peripheral venous catheters is considered one of the major and independent risk factors of catheter-related bloodstream infections ${ }^{30}$.

\section{- Administration of lipids}

The lipid solutions provide high-caloric food intake for the premature infants. However, these emulsions facilitate the growth of microorganisms by suppressing the function of neutrophils and macrophages $^{35}$. The risk of CoNS bacteremia is mainly associated with the use of lipids ${ }^{41}$.

\section{- Mechanical ventilation}

Endotracheal intubation abolishes the cough reflexes, decreases ciliary motility and results in bacterial colonization of the endotracheal tube. This increases the risk of nosocomial pneumonia in the ventilated neonate ${ }^{20}$. The prolonged mechanical ventilation is an independent risk factor for VAP ${ }^{31,35,37 .}$ Researchers from China determined that ventilation for more than 5 days increases the risk of VAP by 4.8 times $^{42}$.

\section{- Hospital stay}

It is generally assumed that prolonged hospital stay increases the risk of nosocomial infection ${ }^{30,35}$. This is hardly surprising, as the sickest babies will stay in hospital longer and will be exposed to different procedures and variety of potential nosocomial pathogens.

\section{- Antibiotics}

Antibiotics and the duration of antibiotic use are associated with an increased risk of infection with multi-resistant microorganisms, invasive fungal infection, necrotizing enterocolitis, late-onset sepsis ${ }^{43-45}$. The use of third generation cephalosporins has been linked to the emergence of extended spectrum $\beta$ - lactamase-producing Klebsiella pneumoniae ${ }^{46}$.

\section{- Understaffing, overcrowding and design of the NICU}

Studies have demonstrated the direct link between ensuring well-trained medical personnel and the rate of infections in NICUs ${ }^{47}$. The recommended nurse to patient ratio is $1: 2^{48}$. Decreasing the distance between incubators increases the risk of NI. The British Association of Perinatal Medicine recommends a distance of 2-4 meters, which ensures $12 \mathrm{~m}^{3}$ for a patient ${ }^{49}$.

\section{- Practices in the nursery}

The newborns in the developing countries are additionally exposed to some external environmental factors, that put them at risk of infection, such as dangerous practices during childbirth. According to World Health Organization (WHO), only 68\% of the women in developing countries receive antenatal care and only $35 \%$ in the most underdeveloped countries have access to trained medical personnel during childbirth $^{50}$. This leads to unhygienic practices, discontinuation of the umbilical cord with non-sterile instruments, inadequate care for the skin of the newborn $^{51}$. The hospitals in developing countries are the main source of neonatal infection for hospital-born infants ${ }^{25}$.

\section{Conclusions}

Nosocomial infections are one of the leading causes of morbidity and mortality in the neonatal period. There are substantial variations in the reported incidence rates of NI in developed and developing countries. Knowing the risk factors and the leading etiological agents of NI is an important step in the development of systems for epidemiologic surveillance and programs for infection control and prevention. 


\section{Authors contributions}

V.R conceived the original draft preparation. V.R, A.K., M.K., were responsible for conception and design of the review. ,V.R. and A.K. were responsible for the collection and assembly of the articles/published data, and their inclusion and interpretation in this review. V.R, A.K. and M.K. contributed equally to the present work. All authors contributed to the critical revision of the manuscript for valuable intellectual content. All authors have read and agreed with the final version of the manuscript.

\section{Compliance with Ethics Requirements:}

„The authors declare no conflict of interest regarding this article"

Acknowledgments: The article has been funded by the National program for young scientists and post-doctoral students.

\section{References}

1. Goldmann DA. Prevention and management of neonatal infections. Infect Dis Clin North Am. 1989; 3:779-813.

2. Horan TC, Andrus M, Dudeck MA. (2008) CDC/NHSN surveillance definition of health care-associated infection and criteria for specific types of infections in the acute care setting. Am J Infect Control. 36: 309-332.

3. Polin RA, Saiman L. Nosocomial Infections in the Neonatal Intensive Care Unit. Neo Reviews. 2003;4(3):81-89.

4. Haley RW, Culver DH, White JW. The efficacy of infection surveillance and control programs in preventing nosocomial infections in US hospitals. Am J Epidemiol. 1985;121:182_ 205.

5. Gaynes RP, Edwards JR, Jarvis WR, Culver DH, Tolson JS, Martone WJ. Nosocomial infections among neonates in high-risk nurseries in the United States. Pediatrics. 1996;98(3 Pt 1):357-61.

6. Patel SJ, Saiman L. Antibiotic resistance in neonatal intensive care unit pathogens: mechanisms, clinical impact, and prevention including antibiotic stewardship. Clin Perinatol. 2010;37(3):547-63.

7. Mussi-Pinhata MM, do Nascimento SD. Neonatal nosocomial infections. Jornal de Pediatria. 2001;77, Suppl 1:S81-S96.

8. Arnoni MV, Berezin EN, Martino MD. Risk factors for nosocomial bloodstream infection caused by multidrug resistant gram-negative bacilli in pediatrics. Braz J Infect Dis. 2007;11(2):267-71.

9. Boyce JM. Vancomycin-resistant enterococcus. Detection, epidemiology, and control measures. Infect Dis Clin North Am. 1997;11(2):367-84.

10. Efird MM, Rojas MA, Lozano JM et al. Epidemiology of nosocomial infections in selected neonatal intensive care units in Colombia, South America. J Perinatol. 2005;25(8):531-6.

11. Diekema DJ, Barr J, Boyken LD et al. A cluster of serious Escherichia coli infections in a neonatal intensive-care unit. Infect Control Hosp Epidemiol. 1997;18(11):774-6.

12. Babazono A, Kitajima H, Nishimaki S et al. Risk factors for nosocomial infections in the neonatal intensive care unit by the Japanese National Infection Surveillance (JANIS). Acta Med Okayama. 2008;62(4):261-26.

13. Mohammed D, El Seifl OS. Bacterial nosocomial infections in neonatal intensive care unit, Zagazig University Hospital, Egypt. Egyptian Pediatric Association Gazette. 2014;62 $(3-4): 72-79$.

14. Francis BM, Gilbert GL. Survey of neonatal meningitis in Australia: 1987-1989. Med J Aust. 1992;156:240-243.

15. Tumbarello M, De Pascale G, Trecarichi EM et al. Clinical outcomes of Pseudomonas aeruginosa pneumonia in intensive care unit patients. Intensive Care Med. 2013;39(4):682-92.

16. Maltezou HC, Kontopidou F, Katerelos P, Daikos G, Roilides E, Theodoridou M. Infections caused by carbapenem-resistant Gram-negative pathogens in hospitalized children. Pediatr Infect Dis J. 2013;32(4):e151-4.

17. Langley JM, Bradley JS. Defining pneumonia in critically ill infants and children. Pediatr Crit Care Med. 2005;6(3 Suppl):S9-S13.

18. Newborn death and illness, Millenium development goal 4 (MDG 4), Available at https://www.who.int/pmnch/media/ press_materials/fs/fs_newborndealth_illness/en/ (accessed 15 Nov 2019)

19. Gaynes RP, Martone WJ, Culver DH, Emori TG, Horan TC, Banerjee SN. Comparison of rates of nosocomial infections in neonatal intensive care units in the United States. National Nosocomial Infections Surveillance System. Am J Med. 1991;91:192S-196S.

20. Peter G, Cashore WJ. Infections acquired in the nursery: Epidemiology and control. In Remington JS, Klein JO,e ds, Infectious Diseases of the Fetus and Newborn Infant, 3rd ed. Philadeplhia: WB Saunders. 1990;1000-1019.

21. Dudeck MA, Weiner LM, Allen-Bridson K. National Healthcare Safety Network (NHSN) report, data summary for 2012, Device-associated module. J Infect Control. 2013;41(12):1148-66.

22. van der Zwet WC, Kaiser AM, van Elburg RM, Nosocomial infections in a Dutch neonatal intensive care unit: surveillance study with definitions for infection specifically adapted for neonates. J Hosp Infect. 2005;61(4):300-11.

23. Aziz K, McMillan DD, Andrews W, et al. Canadian Neonatal Network, Variations in rates of nosocomial infection among Canadian neonatal intensive care units may be practice-related. BMC Pediatr. 2005;5:22.

24. Black RE, Cousens S, Johnson HL, et al. Child Health Epidemiology Reference Group of WHO and UNICEF, Global, regional, and national causes of child mortality in 2008: a systematic analysis. Lancet. 2010;375(9730):1969-87.

25. Zaidi AK, Huskins WC, Thaver D, Bhutta ZA, Abbas Z, Goldmann DA. Hospital-acquired neonatal infections in developing countries. Lancet. 2005;365(9465):1175-88.

26. Klevens RM, Edwards JR, Richards Jr CL et al. Estimating health care-associated infections and deaths in US hospitals, 2002. Public Health Rep. 2007;122:160-166.

27. Gill AW. Australian and New Zealand Neonatal Network, Analysis of neonatal nosocomial infection rates across the Australian and New Zealand Neonatal Network. J Hosp Infect. 2009;72(2):155-62.

28. Zingg W, Hopkins S, Gayet-Ageron A. Health-care-associated infections in neonates, children, and adolescents: an analysis of pediatric data from the European Centre for Disease Prevention and Control point-prevalence survey, Lancet Infect Dis. 2017;17(4):381-389.

29. Orsi GB, d'Ettorre G, Panero A, Chiarini F, Vullo V, Venditti M. Hospital acquired infection surveillance in a neonatal intensive care unit. Am J Infect Control. 2009;37:201-3. 
30. Djordjevic ZM, Markovic-Denic L, Folic MM, Igrutinovic Z, Jankovic SM. Health care-acquired infections in neonatal intensive care units: Risk factors and etiology, Am J Infect Control. 2015;43(1):86 - 88 .

31. Basiri B, Sabzehei MK, Shokouhi M, Moradi A. Evaluating the incidence and risk factors of nosocomial infection in neonates hospitalized in the neonatal intensive care unit of Fatemieh Hospital in Hamadan, Iran, 2012 - 2013. Archives of Pediatric Infectious Diseases. 2015; 3(2): e23327.

32. Urzedo JE, Levenhagen MM, Pedroso RS, Abdallah VO, Sabino SS, Brito DV. Nosocomial infections in a neonatal intensive care unit during 16 years: 1997-2012. Rev Soc Bras Med Trop. 2014;47:321-6.

33. Kilic A, Okulu E, Kocabas BA, et al. Health care-associated infection surveillance: A prospective study of a tertiary neonatal intensive care unit. J Infect Dev Ctries. 2019;13:181-187.

34. Saiman L. Risk factors for hospital-acquired infections in the neonatal intensive care unit. Semin Perinatol. 2002;26(5):315-21.

35. Nagata E, Brito ASJ, Matsuo T. Nosocomial infections in a neonatal intensive care unit: Incidence and risk factors. Am J Infect Control. 2002;30(1):26-31.

36. Różańska A, Wójkowska-Mach J, Adamski P. Infections and risk-adjusted length of stay and hospital mortality in Polish Neonatology Intensive Care Units. Int J Infect Dis. 2015;35:87-92.

37. Stoll BJ, Hansen N, Fanaroff AA et al. Late-onset sepsis in very low birth weight neonates: the experience of the NICHD Neonatal Research Network. Pediatrics. 2002;110(2 Pt 1):285-91.

38. Richardson DK, Gray JE, McCormick MC, Workman K, Goldmann DA. Score for Neonatal Acute Physiology: a physiologic severity index for neonatal intensive care. Pediatrics. 1993;91(3):617-23.

39. The International Neonatal Network, CRIB (clinical risk index for babies) score: a tool for assessing initial neonatal risk and comparing performance of neonatal intensive care units. Lancet. 1993;342(8865):193-8.

40. Mullett MD, Cook EF, Gallagher R. Nosocomial sepsis in the neonatal intensive care unit. J Perinatol. 1998;18(2):112-5.
41. Auriti C, Maccallini A, Di Liso G, Di Ciommo V, Ronchetti MP, Orzalesi M. Risk factors for nosocomial infections in a neonatal intensive-care unit. J Hosp Infect. 2003;53(1):25-30.

42. Yuan TM, Chen LH, Yu HM. Risk factors and outcomes for ventilator-associated pneumonia in neonatal intensive care unit patients. J Perinat Med. 2007;35(4):334-8.

43. Tsai MH, Chu SM, Hsu JF, et al. Risk factors and outcomes for multidrug-resistant Gram-negative bacteremia in the NICU. Pediatrics. 2014; 133: e322-29.

44. Kuppala VS, Meinzen-Derr J, Morrow AL, Schibler KR. Prolonged initial empirical antibiotic treatment is associated with adverse outcomes in premature infants. J Pediatr. 2011;159:720-25.

45. Diaconu C, Balaceanu A, Morosan E. Sepsis biomarkers: past, present and future. Farmacia. 2015;63(6):811-815.

46. Sirot D. Extended-spectrum plasmid-mediated beta-lactamases. J Antimicrob Chemother. 1995;36 Suppl A:19-34.

47. Rogowski JA, Staiger D, Patrick T, Horbar J, Kenny M, Lake ET. Nurse staffing and NICU infection rates. JAMA Pediatr. 2013;167(5):444-50.

48. Marschall J, Mermel LA, Fakih M. Strategies to prevent central line-associated bloodstream infections in acute care hospitals: 2014 update. Infect Control Hosp Epidemiol. 2014;35(7):753-71.

49. Laing I, Ducker T, Leaf A, Newmarch P. Designing a Neonatal Unit. Report for the British Association of Perinatal Medicine. May 2004, Available at: http:// www.bapm.org/publications/documents/guidelines/ DesigningNNU_May2004b.pdf

50. World Health Organization Department of Reproductive Health and Research: Proportion of Births Attended by a Skilled Health Worker. Geneva, World Health Organization,2008.https://www.who.int/reproductivehealth/publications/maternal_perinatal_health/2008_ skilled_attendants/en/

51. Stoll BJ. Neonatal infections: a global perspective, in Remington JS, Klein JO (eds): Infectious Diseases of the Fetus and Newborn Infant (ed 6). Philadelphia, PA, WB Saunders, 2006. 